\title{
Clustering ANd Clusters: A Systemic APPROACH
}

\author{
POPA, H.L.; MOCAN, M.L.; IZVERCIANU, M. \& PATER, L.R.
}

Abstract: The idea, that more general theories are preferred over more specialized theories, lies at the heart of systems science. The systemic approaches of the becoming / change and of the progress lack consistency in the absence of a wholly system of concepts about systems to allow a thorough knowledge and a humanist type orientation of the change, meant for turning the progress into a fundamental process of the Universe / Multiverse. The paper presents by the following contributions: integrative definition of the main concepts of systemics; stressing the fundamental role of the clustering and clusters in the systems change (progress / stagnation / regress) in Universe / Multiverse; functional-structural definition and characterization of clusters, clustering and inoclusters; elaboration of a model for the universal cycle of the systems change which emphasizes the essence of progress.

Key words: systemics, clusters, clustering, becoming cycle, progress
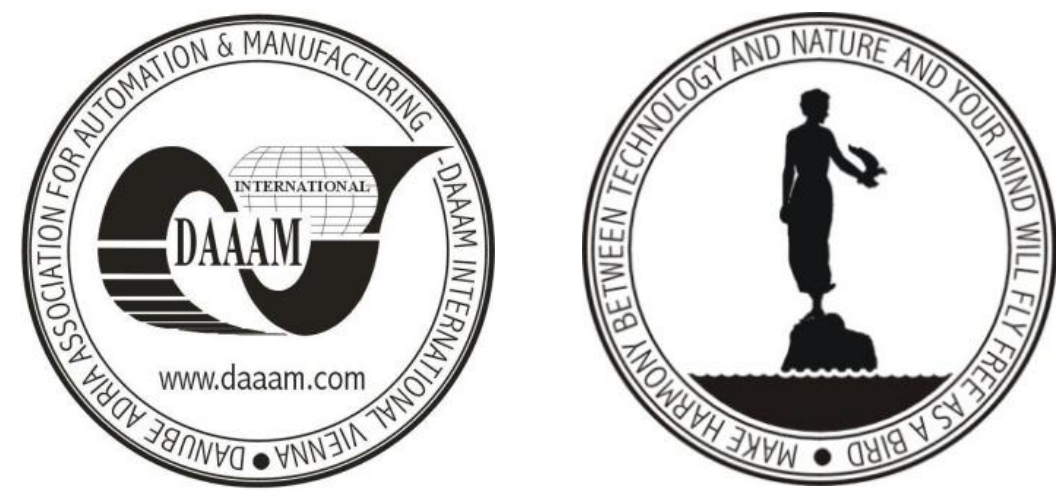

Authors' data: Univ.Prof. Dipl.-Ing. Dr.techn. Popa, H[oria] L[iviu]; Univ.Prof. Dipl.-Ing. Dr.econ. Mocan, M[arian] L[iviu]; Univ.Prof. Dipl.-Ing. Dr.techn. Izvercianu, M[onica]; Univ.Lect. Dipl.-Mat\&Econ. Dr.econ. Pater, L[iana] R[odica], Politehnica University of Timisoara, Management Faculty, 14, Remus Street, 300191, Timisoara, Romania, hpopa@eng.upt.ro, mmocan@expertconsulting.ro, mizvercianu@eng.upt.ro, lianapater@yahoo.com

This Publication has to be referred as: Popa, H[oria] L[iviu]; Mocan, M[arian] L[iviu]; Izvercianu, M[onica] \& Pater, L[iana] R[odica] (2010). Clustering and Clusters: A Systemic Approach, Chapter 19 in DAAAM International Scientific Book 2010, pp. 177-194, B. Katalinic (Ed.), Published by DAAAM International, ISBN 978-3-901509-74-2, ISSN 1726-9687, Vienna, Austria

DOI: $10.2507 /$ daaam.scibook.2010.19 


\section{Introduction}

Irrespective of theories and models of modern science (Dyson, 1989; Adams \& Gregory, 2000; Chaisson, 2001; Harrison, 2003; Dick, 2008) on the Universe / Multiverse (?) (infinite / finite; opened / flat / closed etc.), on the progress (Teilhard, 1948/1956; Stonier, 1990,1992,1997; Moore, 1994; Wright, 2005; Costanza, 2009; Stiglitz, 2009), the becoming / change $(\ldots \rightarrow$ progress $\rightarrow$ stagnation $\rightarrow$ regress $\rightarrow$ stagnation $\rightarrow$ progress $\rightarrow \ldots$ ) is now approached mainly within the subjects or interdisciplinary (Katseneliboigen, 1997). The systemic approaches of the becoming / change and of the progress lack consistency (Umpleby, 2001, 2007) in the absence of a wholly system of concepts about systems (Watson, 1999; Popa, 2003; Castellani \& Haferty, 2009) to allow a thorough knowledge and a humanist type orientation of the becoming / change, meant for turning the progress into a fundamental process of the Universe.

As a general rule, the progress of systemic approach of the reality leads (Banathy, 2000; Popa, 2003) to:

- continuous development of a consistent, robust system and of the system related concepts,

- establishment of hierarchic systemic models (non-mathematic and mathematic), more and more accurate, to reflect the structures and the flows of substance, energy, information (self-organization) in accordance with the present / future evolution of the science, to allow the modelling, effective simulation and optimization of all systems, no matters how complex they are,

- continuous development of the systems theory, philosophy and methodology (systemology / systemics).

The present chapter has in view to:

- define the becoming / change and the progress from a systemic perspective,

- analyse and define clusters and clustering from a systemic perspective as an essential process of the entities becoming / change,

- develop some models, useful in the engineering and management practice of cluster-based progress.

The present chapter makes a minute analysis of a new research and action subdomain called "cluster-based sustainable integrated competitiveness (for unlimited term)", highly important for Romania and the European Union.

Future research will go deeper in the identification and optimization of clustering and clusters / clusters of clusters in other domains of reality.

\section{Basic concepts of systemics}

For the progress of science, the development of systemology / systemics (François, 1999; Watson, 1999; Popa, 2003) is preferred to other numerous notions (holistics, complexity science, new science of networks etc.), which have appeared at the same time with new branches and sub-branches of this synthesis-oriented science. Any systemic approach is based on a consistent, robust, of the system-related concepts. 
System S (in Greek: $\sigma 0 ́ \sigma \tau \eta \mu \alpha$, in Latin: systema) means a multitude of integrated components (elements $\mathbf{E}$ ) in internal determined $\mathbf{M}_{\text {dint }} /$ self-determined $\mathrm{M}_{\text {aint }}$ which interact and function through cooperation and competition (coopetition) under certain space-time-resources circumstances of proximate $M_{\text {pext }}$ external environment, while producing some results in his life cycle, within $\mathrm{D}_{\text {str }}$ space-timeresources domains considered.

In general the cooperation can be assimilated with attraction, cohesion, compromise, compatibility and competition with repulsion, confrontation, rivalry, incompatibility of the components within $D_{\text {str }}$ space-time-resources domains considered.

The Universe / Multiverse are infinite integrated systems of systems $\left\{S_{\mathrm{S}}\right\}$ (agglomerations, networks, and groups etc. of entities) governed by universal / general / characteristic laws (Popa, 2003) which determine the cyclical becoming / change $(\ldots . \rightarrow$ progress $\rightarrow$ stagnation $\rightarrow$ regress $\rightarrow$ stagnation $\rightarrow$ progress $\rightarrow \ldots$ ), the continuous movement within any known $D_{\text {str }}(t)$ space-time-resources domains. The Universe / Multiverse can be consider an infinite hierarchy and diversity of $D_{\text {str }}(t)$ space-time-resources domains.

A $\mathbf{D}_{\text {str }}(\mathbf{t})$ space-time-resources domains means a "portion" of Universe / Multiverse, a supra-system within take place the becoming / change of the components (systems) and his internal environment (milieu). Specific interfaces separate the considerate $D_{\text {str }}(t)$ space-time-resources domains from his external milieu (environment) $\mathbf{M}_{\text {ext. }}$. The systems laws (Kauffman, 1997; Popa, 2003) allows Mankind the knowledge, foresight and, more and more, the control and foresight of phenomenon within $D_{\text {str }}(t)$ space-time-resources domains.

The results of interactions and working of systems within $D_{\text {str }}(t)$ space-timeresources domains during its life cycle, characterised by specific $\{\mathbf{v}\}$ variables, are as follows:

- conscious (for systems that include humans), in which case the results represent the partial or total accomplishment of the competitiveness K(t) (aim / mission / objectives) of the system $\mathbf{S}$, contribute to progress (or, on the contrary, to stagnation / regress), to wellbeing (or, on the contrary, to bad-being) in internal environment and in external proximal milieu $\mathrm{M}_{\text {pext }}$ of $\mathrm{D}_{\text {str }}(\mathrm{t})$ space-time-resources domains,

- unconscious (for systems that do not include humans), in which case the results represent the finality $\mathbf{F}(\mathbf{t})$, the consequence of the system $\mathrm{S}$ interaction with other systems from external environment, contribute to the becoming / change $(\ldots . \rightarrow$ progress $\rightarrow$ stagnation $\rightarrow$ regress $\rightarrow$ stagnation $\rightarrow$ progress $\rightarrow \ldots$...) within $\mathrm{D}_{\text {str }}(\mathrm{t})$ space-time-resources domains.

Any real system $\mathbf{S}_{\mathbf{R}}$ (natural and / or artificial):

-constitutes an integrated whole of its components and, at the same time,

- constitutes, (except for the Universe / Multiverse considered as infinite) a subsystem of a more complex system, respectively of a super-system (system of systems $\mathrm{S}_{\mathrm{S}}$ ) of a less complex component system, within $\mathrm{D}_{\text {str }}(\mathrm{t})$ space-time-resources domains,

-identifies through a system of concepts (Table 1) which characterize any type of system (Popa, 2003; Popa et al., 2009), 
-has a structure (the multitude of its $\mathbf{E}$ components and the relations $\mathbf{R}_{\mathbf{i}}$ among them which determines the system identity, connectivity and functioning in its life cycle) and has in its structure two interconnected functional-structural sub-systems (execution sub-system $\mathbf{S}_{\mathbf{R e x e}}$ and command subsystem $\mathbf{S}_{\mathbf{R c o n}} /$ self-command $\mathbf{S}_{\mathbf{R a c o}}$ ):

\begin{tabular}{|c|c|c|c|c|c|c|c|c|c|}
\hline \multirow[b]{2}{*}{$\begin{array}{l}\begin{array}{r}\text { Systemic } \\
\text { approach }\end{array} \\
\text { C } \\
\text { and } \\
\text { cluster C } \\
\text { components }\end{array}$} & \multicolumn{9}{|c|}{ Characterization of Clusters based on concepts of real systems $\mathbf{S}_{\mathbf{R}}$ (natural and / or artificial) } \\
\hline & $\begin{array}{l}\text { Structure } \\
\mathbf{S}= \\
\mathbf{E} \& \mathbf{R}_{\mathbf{i}}\end{array}$ & $\begin{array}{l}\text { Functio- } \\
\text { ning } \\
\text { programs } \\
\mathbf{P}_{\mathbf{f}}\end{array}$ & $\begin{array}{l}\text { Transfor- } \\
\text { ming } \\
\text { processes } \\
\mathbf{P}_{\mathbf{t}}\end{array}$ & $\begin{array}{l}\text { External } \\
\text { conne- } \\
\text { xions } \mathbf{R}_{\mathbf{e}} \\
=\mathbf{U} \& \mathbf{Y}\end{array}$ & $\begin{array}{l}\text { Varia- } \\
\text { bles }\{\mathbf{v}\}\end{array}$ & $\begin{array}{l}\text { Exten- } \\
\text { sions / } \\
\text { limits } \\
\mathbf{L}\end{array}$ & $\begin{array}{l}\text { Milieu } \\
\mathbf{M}= \\
\mathbf{M}_{\text {int }} \& \\
\mathbf{M}_{\text {ext }}\end{array}$ & $\begin{array}{l}\text { Global } \\
\text { function } \\
/ \text { mission } \\
\mathbf{F}_{\mathbf{g}}\end{array}$ & $\begin{array}{l}\text { Purpose } \\
\text { (competi- } \\
\text { tivenessK } \\
\text { /Finality) }\end{array}$ \\
\hline $\begin{array}{l}\text { ClusterC } \\
\text { - natural } \\
\text { - artificial }\end{array}$ & $\begin{array}{l}\text { compo- } \\
\text { nents } \mathbf{E} \\
{[\mathbf{1}]+[\mathbf{2}]+} \\
{[3]+[\mathbf{4}] \&} \\
\text { intercon- } \\
\text { nexions } \\
\mathrm{R}_{\mathrm{i}}\end{array}$ & $\begin{array}{l}\text { P integra- }_{\text {fint, elabo- }} \\
\text { ted, } \\
\text { rate } \\
\text { through } \\
\text { initiative of } \\
\text { [1] and } \\
\mathbf{M}_{\text {aint }} \text { of } \mathbf{C}\end{array}$ & $\begin{array}{l}\mathbf{P}_{\mathbf{t}} \text { specific } \\
\text { integrated } \\
\text { processes on } \\
\text { components } \\
{[\mathbf{1}]+[2]+[3]} \\
+[\mathbf{4}] \text { of } \mathbf{C}\end{array}$ & $\begin{array}{l}\mathbf{R}_{\mathbf{e}} \text { with } \\
\text { domain } \\
D_{\text {str }} \text { input } \\
\text { U / output } \\
\text { Y speci- } \\
\text { fic for } \mathbf{C}\end{array}$ & $\begin{array}{l}\text { state va- } \\
\text { riabiles } \\
\text { / input / } \\
\text { output } \\
\mathbf{X} / \mathbf{U} \text { / } \\
\mathbf{Y} \text { of } \mathbf{C}\end{array}$ & $\begin{array}{l}\text { fron- } \\
\text { tier } \mathbf{L} \\
\text { of } \mathbf{C} \text {, } \\
\text { fluctu- } \\
\text { ating, } \\
\text { porous }\end{array}$ & $\begin{array}{l}\text { proxi- } \\
\text { mate } \\
\text { do- } \\
\text { main } \\
\mathrm{D}_{\text {str }} \text { of } \\
\text { C }\end{array}$ & $\begin{array}{l}\text { transfor- } \\
\text { mation } \\
\text { input U } \\
\text { in } \\
\text { output } \\
\text { Y of } \mathbf{C}\end{array}$ & $\begin{array}{l}\mathbf{K}_{\mathrm{sC}} \\
\text { sustai- } \\
\text { nable } \\
\text { competi- } \\
\text { tiveness } \\
\text { of cluster } \\
\mathbf{C} / \text { result }\end{array}$ \\
\hline $\begin{array}{l}\text { - Self- } \\
\text { determined } \\
\text { internal } \\
\text { environment } \\
\text { (milieu) } \\
\mathbf{M}_{\text {aint }} \text { of } \mathbf{C}\end{array}$ & $\begin{array}{l}\text { compo- } \\
\text { nents }[1] \\
+[2]+[3] \\
\text { and } \\
\text { intercon- } \\
\text { nexions }\end{array}$ & $\begin{array}{l}\mathbf{P}_{\mathbf{f}} \text { elaborate } \\
\text { together } \\
{[\mathbf{1}]+[2]+[3]} \\
\text { and } \\
\text { integrated } \\
\text { for } \mathbf{C}\end{array}$ & $\begin{array}{l}\mathbf{P}_{\mathbf{t}} \text { specific } \\
\text { integrated } \\
\text { processes on } \\
\text { components } \\
{[\mathbf{1}]+[\mathbf{2}]+[\mathbf{3}]} \\
\text { of } \mathbf{C}\end{array}$ & $\begin{array}{l}\mathbf{R}_{\mathrm{e} p r e-} \\
\text { valent } \\
\text { through } \\
\text { [1] and } \\
\text { collateral } \\
\text { through } \\
{[2]+[3]}\end{array}$ & $\begin{array}{l}\text { state va- } \\
\text { riabiles } \\
\text { / input / } \\
\text { output } \\
\mathbf{X} / \mathbf{U} \text { / } \\
\mathbf{Y} \text { of } \mathbf{C}\end{array}$ & $\begin{array}{l}\text { Fron- } \\
\text { tier } \mathbf{L} \\
\text { of } \\
\mathbf{M}_{\text {aint }} \text {, } \\
\text { fluctu- } \\
\text { ating, } \\
\text { porous }\end{array}$ & $\begin{array}{l}\text { milieu } \\
\text { M } \\
\text { speci- } \\
\text { fic for } \\
\text { C }\end{array}$ & $\begin{array}{l}\text { determi- } \\
\text { nation } \\
\text { of } \mathbf{C} \\
\text { existen- } \\
\text { ce }\end{array}$ & $\begin{array}{l}\mathbf{K}_{\mathbf{C}} \text { of } \\
\text { cluster } \mathbf{C} \\
\text { / result }\end{array}$ \\
\hline $\begin{array}{l}\text { [1]Comint } \\
\text { Internal } \\
\text { community } \\
\text { (give identity } \\
\text { of } \mathbf{C} \text { ) }\end{array}$ & $\begin{array}{l}\text { compo- } \\
\text { nents and } \\
\text { specific } \\
\text { intercon- } \\
\text { nexions } \\
\text { for [1] }\end{array}$ & $\begin{array}{l}\mathbf{P}_{\mathbf{f}} \text { elaborate } \\
\text { for achiev- } \\
\text { ement } \mathrm{Y}_{1} \\
\text { and } \\
\mathrm{K}_{1} \& \mathrm{~K}_{\mathrm{C}}\end{array}$ & $\begin{array}{l}\mathbf{P}_{\mathbf{t}} \text { specific } \\
\text { integrated for } \\
\text { achievement } \\
\text { of } \mathrm{Y}_{1} \text { and } \\
\mathrm{K}_{1} \& \mathrm{~K}_{\mathrm{C}}\end{array}$ & $\begin{array}{l}\text { input } \mathbf{U}_{1} \\
\text { and } \\
\text { output } \mathbf{Y}_{\mathbf{1}} \\
\text { specific } \\
\text { for [1] }\end{array}$ & $\begin{array}{l}\text { state va- } \\
\text { riabiles } \\
\text { / input / } \\
\text { output } \\
\mathbf{X} / \mathbf{U} \text { / } \\
\mathbf{Y} \text { of [1] }\end{array}$ & $\begin{array}{l}\text { Fron- } \\
\text { tier } \mathbf{L} \\
\text { of [1], } \\
\text { fluctu- } \\
\text { ating, } \\
\text { porous }\end{array}$ & $\begin{array}{l}\text { milieu } \\
M \\
\text { speci- } \\
\text { fic for } \\
{[1]}\end{array}$ & $\begin{array}{l}\text { produc- } \\
\text { tion } \\
\text { output } \\
\mathbf{Y} \text { of } \mathbf{C}\end{array}$ & $\begin{array}{l}\mathbf{K}_{1} \text { of } \\
\text { Comint / } \\
\text { result } \\
\mathbf{K}_{\mathbf{C}} \text { of } \\
\text { cluster / } \\
\text { result }\end{array}$ \\
\hline $\begin{array}{l}\text { [2]Facilit } \\
\text { Internal and / } \\
\text { or external } \\
\text { facilitators } \\
\text { (for coope- } \\
\text { ration and } \\
\text { competiti- } \\
\text { veness of } \mathbf{C} \text { ) }\end{array}$ & $\begin{array}{l}\text { compo- } \\
\text { nents and } \\
\text { specific } \\
\text { intercon- } \\
\text { nexions } \\
\text { for [2] }\end{array}$ & $\begin{array}{l}\mathbf{P}_{\mathrm{f}} \text { elaborate } \\
\text { for achiev- } \\
\text { ement } \mathrm{Y}_{2} \\
\text { and } \\
\mathrm{K}_{2} \& \mathrm{~K}_{\mathrm{C}}\end{array}$ & $\begin{array}{l}\mathbf{P}_{\mathrm{t}} \text { specific } \\
\text { integrated for } \\
\text { achievement } \\
\text { of } \mathrm{Y}_{2} \text { and } \\
\mathrm{K}_{2} \& \mathrm{~K}_{\mathrm{C}}\end{array}$ & $\begin{array}{l}\text { input } \mathbf{U}_{2} \\
\text { and } \\
\text { output } \mathbf{Y}_{2} \\
\text { specific } \\
\text { for [2], } \\
\text { for } \mathbf{C}\end{array}$ & $\begin{array}{l}\text { state va- } \\
\text { riabiles } \\
\text { / input / } \\
\text { output } \\
\mathbf{X} / \mathbf{U} \text { / } \\
\mathbf{Y} \text { of [2] }\end{array}$ & $\begin{array}{l}\text { Fron- } \\
\text { tier } \mathbf{L} \\
\text { of [2], } \\
\text { fluctu- } \\
\text { ating, } \\
\text { porous }\end{array}$ & $\begin{array}{l}\text { milieu } \\
M \\
\text { speci- } \\
\text { fic for } \\
{[2]}\end{array}$ & $\begin{array}{l}\text { stimu- } \\
\text { late } \\
\text { coope- } \\
\text { ration \& } \\
\text { compe- } \\
\text { titive- } \\
\text { nessC }\end{array}$ & $\begin{array}{l}\mathbf{K}_{\mathbf{2}} \text { of } \\
\text { Facilit / } \\
\text { result } \\
\mathbf{K}_{\mathbf{C}} \text { of } \\
\text { cluster / } \\
\text { result }\end{array}$ \\
\hline $\begin{array}{l}{[3]} \\
\text { DetintDeter } \\
\text { minantsof } \\
\text { internal } \\
\text { environment } \\
\text { (C life and } \\
\text { functioning) }\end{array}$ & $\begin{array}{l}\text { compo- } \\
\text { nents and } \\
\text { specific } \\
\text { intercon- } \\
\text { nexions } \\
\text { for [3] }\end{array}$ & $\begin{array}{l}\mathbf{P}_{\mathrm{f}} \text { elaborate } \\
\text { for achiev- } \\
\text { ement } \mathrm{Y}_{3} \\
\text { and } \\
\mathrm{K}_{3} \& \mathrm{~K}_{\mathrm{C}}\end{array}$ & $\begin{array}{l}\mathbf{P}_{\mathbf{t}} \text { specific } \\
\text { integrated for } \\
\text { achievement } \\
\text { of } \mathrm{Y}_{3} \text { and } \\
\mathrm{K}_{3} \& \mathrm{~K}_{\mathrm{C}}\end{array}$ & $\begin{array}{l}\text { input } \\
\mathbf{U}_{3} \text { and } \\
\text { output } \\
\mathbf{Y}_{\mathbf{3}} \text { specifi } \\
\text { c for [3], } \\
\text { for } \mathbf{C}\end{array}$ & $\begin{array}{l}\text { state va- } \\
\text { riabiles } \\
\text { / input / } \\
\text { output } \\
\mathbf{X} / \mathbf{U} \text { / } \\
\mathbf{Y} \text { of [3] }\end{array}$ & $\begin{array}{l}\text { Fron- } \\
\text { tier } \mathbf{L} \\
\text { of [3], } \\
\text { fluctu- } \\
\text { ating, } \\
\text { porous }\end{array}$ & $\begin{array}{l}\text { milieu } \\
M \\
\text { speci- } \\
\text { fic for } \\
{[3]}\end{array}$ & $\begin{array}{l}\text { generate } \\
\text { prere- } \\
\text { quisite } \\
\text { for } \\
\mathbf{M}_{\text {aint }} \text { of } \\
\text { C }\end{array}$ & $\begin{array}{l}\mathbf{K}_{3} \text { of } \\
\text { Detint / } \\
\text { result } \\
\mathbf{K}_{\mathbf{C}} \text { of } \\
\text { cluster / } \\
\text { result }\end{array}$ \\
\hline $\begin{array}{l}\text { - Target } \\
\text { proximate } \\
\text { external } \\
\text { environment } \\
\text { (milieu) } \\
\left\{\mathbf{M}_{\text {pext }}\right\} \text { of } \mathbf{C}\end{array}$ & $\begin{array}{l}\text { integrated } \\
\text { external } \\
\text { environ- } \\
\text { ments }\end{array}$ & $\begin{array}{l}\mathbf{P}_{\mathbf{f}} \text { specific } \\
\text { integrated } \\
\text { in } \\
\text { domain } D_{\text {str }} \\
\text { which } \\
\text { incorporate } \\
\text { cluster C }\end{array}$ & $\begin{array}{l}\mathbf{P}_{\mathbf{t}} \text { specific } \\
\text { integrated in } \\
\text { domain } D_{\text {str }} \\
\text { which } \\
\text { incorporate } \\
\text { cluster C }\end{array}$ & $\begin{array}{l}\mathbf{R}_{\mathbf{e}} \text { with } \\
\text { domain } \\
\mathrm{D}_{\text {str }} \text { envi- } \\
\text { ronement: } \\
\text { specific } \\
\text { input U / } \\
\text { output Y }\end{array}$ & $\begin{array}{l}\text { state va- } \\
\text { riabiles } \\
\text { / input / } \\
\text { output } \\
\mathbf{X} / \mathbf{U} / \\
\mathbf{Y} \\
\text { specific } \\
\left\{\mathbf{M}_{\text {pext }}\right\}\end{array}$ & $\begin{array}{l}\text { Fron- } \\
\text { tier } \mathbf{L} \\
\text { of } \\
\left\{\mathbf{M}_{\text {pext }}\right. \\
\}, \\
\text { fluctu- } \\
\text { ating, } \\
\text { porous }\end{array}$ & $\begin{array}{l}\text { proxi- } \\
\text { mate } \\
\text { do- } \\
\text { main } \\
\mathrm{D}_{\text {str }}\end{array}$ & $\begin{array}{l}\text { locali- } \\
\text { zation } \\
\text { of } \\
\text { external } \\
\text { con- } \\
\text { nectors } \\
{[4]}\end{array}$ & $\begin{array}{l}\mathbf{K}_{\mathbf{D}} \text { for } \\
\text { domain } \\
D_{\text {str }} \\
\text { which } \\
\text { incorpo- } \\
\text { rate } \\
\text { cluster C / } \\
\text { result }\end{array}$ \\
\hline $\begin{array}{l}\text { [4] Conext } \\
\text { External } \\
\text { connectors } \\
\text { (initial sup- } \\
\text { pliers and } \\
\text { final consu- } \\
\text { mers for } \mathbf{C} \text { ) } \\
\text { from }\left\{\mathbf{M}_{\text {pext }}\right\} \\
\text { of } \mathbf{C}\end{array}$ & $\begin{array}{l}\text { compo- } \\
\text { nents and } \\
\text { specific } \\
\text { intercon- } \\
\text { nexions } \\
\text { for [4] }\end{array}$ & $\begin{array}{l}\mathbf{P}_{\mathrm{f}} \text { specific } \\
\text { for each } \\
\text { external } \\
\text { connector }\end{array}$ & $\begin{array}{l}\mathbf{P}_{\mathbf{t}} \text { specific for } \\
\text { each } \\
\text { external } \\
\text { connector }\end{array}$ & $\begin{array}{l}\mathbf{R}_{\mathbf{e}} \\
\text { specific } \\
\text { for: } \\
\text { initial } \\
\text { suppliers } \\
\mathrm{Y}_{\text {ini }} / \text { final } \\
\text { consu- } \\
{\text { mers } \mathrm{U}_{\text {fin }}}\end{array}$ & $\begin{array}{l}\text { state va- } \\
\text { riabiles } \\
\text { / input / } \\
\text { output } \\
\mathbf{X} / \mathbf{U} \text { / } \\
\text { Y of } \\
\text { compo- } \\
\text { nents } \\
\text { [4] }\end{array}$ & $\begin{array}{l}\text { Fron- } \\
\text { tier } \mathbf{L} \\
\text { of [4], } \\
\text { fluctu- } \\
\text { ating, } \\
\text { porous }\end{array}$ & $\begin{array}{l}\text { milieu } \\
M \\
\text { speci- } \\
\text { fic for } \\
{[4]}\end{array}$ & $\begin{array}{l}\text { supply } \\
\text { initial } \\
\text { input } \mathbf{U} \\
\text { /consum } \\
\text {-ption } \\
\text { final } \\
\text { output } \\
\text { Y of } \mathbf{C}\end{array}$ & $\begin{array}{l}\mathbf{K}_{\mathbf{4}} \text { useful } \\
\text { for cluster } \\
\mathbf{K}_{\mathbf{C}} / \\
\text { result }\end{array}$ \\
\hline
\end{tabular}

Tab. 1. The systemic approach and characterisation of clusters $\mathrm{C}$ components 
1) execution sub-system $\mathbf{S}_{\text {Rexe }}$ which achieves / ensures the transformation processes $\mathbf{P}_{\mathfrak{t}}$ of $\vec{U}$ entries (substance $\mathrm{S}$, energy E, information I) into $\vec{Y}$ exits (of a substantial, energetic, information type with a preponderance S / E / I, specific for the identity of system $\mathbf{S}_{\mathbf{R}}$ ),

2) command subsystem $\mathbf{S}_{\mathbf{R c o n}} /$ self-command $\mathbf{S}_{\mathbf{R a c o}}$, which achieves / ensures the steering processes $P_{c}$ of the $S_{R}$ system by means of external functioning programs $\mathbf{P}_{\mathbf{f}}$ (of command, elaborated in an exogenous way) and internal functioning programs (self-command, elaborated in an exogenous, unconscious or conscious way).

The system hierarchy and diversity is infinite in space-time-resources due to the dynamics of infinite interconnections ,... - systems $\mathbf{S}$ - environment $\mathbf{M}$ systems $\mathbf{S}$ - ...." in the Universe / Multiverse:

(1) on the unlimited multitude of hierarchic levels $\{n\}$ (over-ordination / subordination of systems) and

(2) at the same hierarchic level $\mathrm{n}$ (by coopetition = cooperation \& competition / coordination of systems).

The frontier of a system is the limit (limits L) by means of which an active and conscious observer separates, according to its own interests of knowledge / action / command / self-command etc.,

- the internal environment / environments

- the external environment / environments

The environments $\mathbf{M}_{\mathbf{S}}$ of systems are delimited space-time-resources domain $\mathrm{D}_{\text {str }}(\mathrm{t})$, from a structural-functional viewpoint, internally simultaneous (overordination) / external (subordination), by means of:

- connexion interfaces $\mathbf{L}_{\mathbf{I}}$ (action / transfer / confrontation / cooperation / compromise), specific for the systems and real environments considered,

- frontiers of identification $\mathbf{L}_{\mathbf{F}}$, defined by a human observer (individual or collective) in accordance with the aims to be followed in the system modelling / knowledge / research / exploitation / command / self-command (frontiers do not always coincide with the system interfaces).

The relations between the system and the external environment are unfold through the $\mathbf{L}_{\mathbf{I}}$ interfaces, specific for each system and are called:

- $\vec{U}$ input / entries (connexions / actions of external environment on the system), expressing the demand (needs) of the system for its external environment and, partially, the offer of the external environment,

- $\vec{Y}$ output / exits entries (connexions / actions of external environment on the system), expressing the offer of the system for its external environment and, partially, the demands (needs) of the external environment.

The real systems $\mathbf{S}_{\mathbf{R}}$ (natural and / or artificial) are identified by means of a system of concepts (Table 1) which characterizes any category of system (Popa, 2003):

$$
S_{R}=\left\{E \& R_{i}, P_{f}, P_{t}, U \& Y, v, L, M_{\text {int }} \& M_{e x t}, F_{g}, K / F\right\}
$$

These concepts allow a rigorous defining of the notion of cluster. 
The progress in the Universe / Multiverse is a category of the becoming / change and it is achieved in the space-time-resources domain $D_{\text {str }}(t)$ of various dimensions, embedded hierarchic levels, characteristics and life durations, within the life cycle of the various $\mathrm{D}_{\text {str }}(\mathrm{t})$ components (systems). As a general rule:

- progress is defined by the system evolution whose characteristics is the cyclic, temporary or lasting / sustainable (unlimited) increase of $\mathbf{K}(\mathbf{t})$ competitiveness (Resource availability in the proximal external environment, Competing capability, Flexibility, Value, Demand in the proximal external environment, Efficiency), of the structural-functional complexity $\mathbf{W}(\mathbf{t})$, of the diversity $\mathbf{Z}(\mathbf{t})$ and of the $\mathbf{B}(\mathbf{t})$ welfare of entities in the hierarchy of the system internal and external environments in a living space-time-resources domain $\mathbf{D}_{\text {str }}(\mathbf{t})$,

- stagnation is defined by the system behaviour with temporary or lasting / sustainable (unlimited) maintenance of $\mathbf{K}(\mathbf{t})$ competitiveness, of the structuralfunctional complexity $\mathbf{W}(\mathbf{t})$, of the diversity $\mathbf{Z}(\mathbf{t})$ and of the $\mathbf{B}(\mathbf{t})$ welfare of entities in the hierarchy of the system internal and external environments in a space-timeresources domain $\mathrm{D}_{\text {str }}(\mathrm{t})$,

- regress is defined by the system involution whose characteristics is the cyclic, temporary or lasting decrease of $\mathbf{K}(\mathbf{t})$ competitiveness, of the structural-functional complexity $\mathbf{W}(\mathbf{t})$, of the diversity $\mathbf{Z}(\mathbf{t})$ and of the $\mathbf{B}(\mathbf{t})$ welfare of entities in the hierarchy of the system internal and external environments in a space-time-resources domain $\mathrm{D}_{\text {str }}(\mathrm{t})$.

Competitiveness $\mathbf{K}(\mathbf{t})$ of a conscious $\mathbf{S}_{\mathrm{cu}}$ system is integrating in a $\Delta \mathrm{t}$ time period, in a space-time-resources domain $\mathrm{D}_{\text {str }}(\mathrm{t})$ (Popa, 2002, 2005, 2008) the following:

- Availability of $\mathbf{D}_{\mathbf{R}}$ resources for the $S_{\mathrm{cu}}$ conscious system as a result of the meeting of the real / effective demand of consumers in the proximal external environment $M_{\text {pext }}$ by the offer of the conscious system $\left(D_{R}\right.$ is an effect of values exchange in the space-time-resources domain $\mathrm{D}_{\text {str }}(\mathrm{t})$;

- Competing capacity $\mathbf{C}_{\mathrm{K}}$ of the $\mathrm{S}_{\mathrm{cu}}$ system;

- Offer $\mathbf{O}_{\text {Scu }}$ of the $\mathbf{S}_{\mathrm{cu}}$ system for the proximal external environment $\mathrm{M}_{\text {pext }}$, offer that, in its turn, integrates: Flexibility $\mathbf{F}$ - the variety / diversity of $Y$ exits or $\{i\}$ products, the $\mathrm{Q}_{\mathrm{i}}$ quantity, the $\mathrm{T}_{\text {cai }}$ assimilating times of $\{\mathrm{i}\}$ variety / diversity, the $\mathrm{T}_{\mathrm{pi}}$ processing times of $\mathrm{R}(\mathrm{t})$ resources necessary for achieving the $\{\mathrm{i}\}$ variety / diversity; Value $\mathbf{V}$ - the $\mathrm{N}_{\mathrm{gi}}$ level of $\{\mathrm{i}\}$,products" global quality of the $\mathrm{S}_{\mathrm{cu}}$ system and the $\mathrm{C}_{\mathrm{ci}}$ level of complete resource consumption necessary for achieving the $\{i\}$,products”;

- Clustering level in the proximal external environment $\mathrm{M}_{\text {pext }}$ available for the $\mathbf{S}_{\mathrm{cu}}$ system;

- Demand $\mathbf{C}_{\text {Mpext }}\left[\left(\right.\right.$ needs $\left.\{\mathrm{i}\} \& \mathrm{~N}_{\mathrm{gi}} \& \mathrm{Q}_{\mathrm{i}} \& \mathrm{~T}_{\mathrm{i}}\right) \&$ (exchange of available values)] of consumers in the proximal external environment $\mathrm{M}_{\text {pext }}$ of $\{i\}$,products" in the $\mathrm{S}_{\mathrm{cu}}$ conscious system;

- Efficiency E (energetic, ecological, economical, ergonomical, aesthetical, social etc.) of the creation, operation by regular restructuring and termination of $S_{c u}$ system;

- Characteristics of conjunctures: $\mathbf{I}_{\mathbf{p}}$ (of proximal external environment $\mathbf{M}_{\text {pext }}$ ) and $\mathbf{I}_{\mathbf{M}}$ (of over-ordinate external environment hierarchy) specific for the external environments of the $S_{\mathrm{cu}}$ conscious system. 
The determinant factors of becoming / change in a space-time-resources domain $\mathrm{D}_{\text {str }}(\mathrm{t})$ are very numerous. The categories of changing factors and their origin are presented in Table 2.

\begin{tabular}{|c|c|c|c|c|}
\hline \multirow[t]{2}{*}{ Factors } & \multicolumn{4}{|c|}{ Categories in accordance with factors origin } \\
\hline & $\begin{array}{l}\text { Components of } \\
\mathrm{D}_{\text {str }}(\mathrm{t}) \text { domain and her } \\
\text { competitiveness }\end{array}$ & $\begin{array}{l}\text { Proximate external } \\
\text { environment } \mathrm{M}_{\text {pext }} \text { of the } \\
\text { components of } \\
\mathrm{D}_{\text {str }}(\mathrm{t}) \text { domain }\end{array}$ & $\begin{array}{l}\text { Self-determined } \\
\text { internal } \\
\text { environment } M_{\text {aint }} \\
\text { of } D_{\text {str }}(t)\end{array}$ & $\begin{array}{c}\text { External } \\
\text { environment of } \\
\mathrm{D}_{\mathrm{str}}(\mathrm{t})\end{array}$ \\
\hline $\begin{array}{l}\text { Progress }(+) \\
\text { progress cycle } \\
\text { within } D_{\text {str }}(t) \\
\text { domain through: } \\
\text { - functional } \\
\text { cycles } \mathrm{c}=1,2 \text {, } \\
\ldots ., \mathrm{f} \\
\text { - system } \\
\text { generations } \mathrm{g}=1 \text {, } \\
2, \ldots ., \mathrm{s}, \ldots .\end{array}$ & $\begin{array}{l}\text { - Integrated available } \\
\text { competitive and } \\
\text { renewable Resources } \mathbf{R}_{\mathbf{i}} \\
(\mathbf{t}) \\
\text { - Complexity } \mathbf{W}(\mathbf{t}) \text { of } \\
\text { entities }\left\{\mathrm{E}_{\mathrm{K}}\right\} \\
\text { - Diversity } \mathbf{Z}(\mathbf{t}) \text { of } \\
\text { entities }\left\{\mathrm{E}_{\mathrm{K}}\right\} \\
\text { - Integrative-innovative } \\
\text { competitive } \mathbf{K}(\mathbf{t}) \\
\text { Clusters } \mathbf{C}_{\mathbf{i n o}} \\
\text { (resources, execution, } \\
\text { govern \& clusters of } \\
\text { clusters }\left\{\mathrm{E}_{\mathrm{K}}\right\} \text { ) } \\
\text { - Competitive } \mathbf{K}(\mathbf{t}) \\
\text { entities }\left\{\mathrm{E}_{\mathrm{K}}\right\}\end{array}$ & $\begin{array}{l}\text { - Periodical stability of } \\
\text { proximate external } \\
\text { environment } \mathrm{M}_{\text {pext }} \text { of the } \\
\text { components of } \\
\mathrm{D}_{\text {str }}(\mathrm{t}) \text { domain } \\
\text { - Positive demand (+) } \\
\mathbf{C}_{\text {Mpext }} \text { of consumers } \\
\text { within proximate } \\
\text { external environment } \\
\mathrm{M}_{\text {pext }} \text { for ,products" }\{\mathrm{i}\} \\
\text { of }\left\{\mathrm{E}_{\mathrm{K}}\right\} \text { entities } \\
\text { - Cyclical characteristics } \\
\mathbf{I}_{\mathbf{p}} \text { (conjuncture) of } \\
\text { proximate external } \\
\text { environment } \mathrm{M}_{\text {pext }}\end{array}$ & $\begin{array}{l}\text { - Periodical } \\
\text { stability of } \\
\text { internal } \\
\text { environment of } \\
\mathrm{D}_{\text {str }}(\mathrm{t}) \text { domain } \\
\text { - Cyclical } \\
\text { characteristics } \\
\mathbf{I}_{\mathbf{M D}} \text { (conjuncture) } \\
\text { of internal } \\
\text { environment of } \\
\mathrm{D}_{\text {str }}(\mathrm{t}) \text { domain }\end{array}$ & $\begin{array}{l}\text { - Periodical } \\
\text { stability of } \\
\text { external } \\
\text { environment of } \\
\mathrm{D}_{\text {str }}(\mathrm{t}) \text { domain } \\
\text { - Cyclical } \\
\text { characteristics } \\
\mathbf{I}_{\mathbf{M}}(\text { conjuncture }) \\
\text { of the hierarchy } \\
\text { of } \\
\text { external } \\
\text { environment of } \\
\mathrm{D}_{\text {str }}(\mathrm{t}) \text { domain }\end{array}$ \\
\hline $\begin{array}{l}\text { Stagnation }(\approx) \\
\text { stagnation cycle } \\
\text { within } D_{\text {str }}(t) \\
\text { domain through: } \\
\text { - functional } \\
\text { cycles } \mathrm{c}=1,2 \text {, } \\
\ldots ., \mathrm{f} \\
\text { - system } \\
\text { generations } \mathrm{g}=1 \text {, } \\
2, \ldots ., \mathrm{s}, \ldots . .\end{array}$ & $\begin{array}{l}\text { - Available and } \\
\text { renewable Resources } \mathbf{R}_{\mathbf{i}} \\
\text { (t) } \\
\text { - Preclusters PC and } \\
\text { Clusters } \mathbf{C} \text { (resources, } \\
\text { execution, govern \& } \\
\text { clusters of clusters } \\
\left\{\mathrm{E}_{\mathrm{K}}\right\} \text { ) } \\
\text { - Insufficient } \\
\text { competitive / non- } \\
\text { competitive entities } \\
\left\{\mathrm{E}_{\mathrm{K}}\right\}\end{array}$ & $\begin{array}{l}\text { - Relative instability of } \\
\text { proximate external } \\
\text { environment } \mathrm{M}_{\text {pext }} \text { of the } \\
\text { components of } \mathrm{D}_{\text {str }}(\mathrm{t}) \\
\text { domain } \\
\text { - Stagnant demand }(\approx) \\
\mathbf{C}_{\text {Mpext }} \text { of consumers } \\
\text { within proximate } \\
\text { external environment } \\
\mathrm{M}_{\text {pext }} \text { for ,products” }\{\mathrm{i}\} \\
\text { of }\left\{\mathrm{E}_{\mathrm{K}}\right\} \text { entities } \\
\text { - Cyclical characteristics } \\
\mathbf{I}_{\mathbf{p}}(\text { conjuncture }) \text { of } \\
\text { proximate external } \\
\text { environment } \mathrm{M}_{\text {pext }}\end{array}$ & $\begin{array}{l}\text { - Relative } \\
\text { instability of } \\
\text { internal } \\
\text { environment of } \\
\mathrm{D}_{\text {str }}(\mathrm{t}) \text { domain } \\
\text { - Cyclical } \\
\text { characteristics } \\
\mathbf{I}_{\mathrm{MD}} \text { (conjuncture) } \\
\text { of internal } \\
\text { environment of } \\
\mathrm{D}_{\text {str }}(\mathrm{t}) \text { domain }\end{array}$ & $\begin{array}{l}\text { - Relative } \\
\text { instability of } \\
\text { external } \\
\text { environment of } \\
\mathrm{D}_{\text {str }}(\mathrm{t}) \text { domain } \\
\text { - Cyclical } \\
\text { characteristics } \\
\mathbf{I}_{\mathbf{M}}(\text { conjuncture }) \\
\text { of the hierarchy } \\
\text { of } \\
\text { external } \\
\text { environment of } \\
\mathrm{D}_{\text {str }}(\mathrm{t}) \text { domain }\end{array}$ \\
\hline $\begin{array}{l}\text { Regress }(-) \\
\text { regress cycle } \\
\text { within } D_{\text {str }}(t) \\
\text { domain through: } \\
\text { - functional } \\
\text { cycles } \mathrm{c}=1,2 \text {, } \\
\ldots \ldots, \mathrm{f} \\
\text { - system } \\
\text { generations } \mathrm{g}=1 \text {, } \\
2, \ldots ., \mathrm{s}, \ldots .\end{array}$ & $\begin{array}{l}\text { - Insufficient available } \\
\text { Resources } \mathbf{R}_{\mathbf{i}}(\mathbf{t}) \\
\text { - Non-competitive } \\
\text { Preclusters PC and } \\
\text { Clusters } \mathbf{C} \text { (resources, } \\
\text { execution, govern \& } \\
\text { clusters of clusters } \\
\left\{E_{K}\right\} \text { ) } \\
\text { - Non-competitive } \\
\text { entities }\left\{E_{K}\right\}\end{array}$ & $\begin{array}{l}\text { - Instability of proximate } \\
\text { external environment } \\
\mathrm{M}_{\text {pext }} \text { of the components } \\
\text { of } \mathrm{D}_{\text {str }}(\mathrm{t}) \text { domain } \\
\text { - Negative demand (-) } \\
\mathbf{C}_{\text {Mpext }} \text { of consumers } \\
\text { within proximate } \\
\text { external environment } \\
\mathrm{M}_{\text {pext }} \text { for ,pproducts" }\{\mathrm{i}\} \\
\text { of }\left\{\mathrm{E}_{\mathrm{K}}\right\} \text { entities } \\
- \text { Cyclical characteristics } \\
\mathbf{I}_{\mathbf{p}} \text { (conjuncture) of } \\
\text { proximate external } \\
\text { environment } \mathrm{M}_{\text {pext }}\end{array}$ & $\begin{array}{l}\text { - Instability of } \\
\text { internal } \\
\text { environment of } \\
D_{\text {str }}(t) \text { domain } \\
\text { - Cyclical } \\
\text { characteristics } \\
\mathbf{I}_{M D} \text { (conjuncture) } \\
\text { of internal } \\
\text { environment of } \\
D_{\text {str }}(t) \text { domain }\end{array}$ & $\begin{array}{l}\text { - Instability of } \\
\text { external } \\
\text { environment of } \\
\mathrm{D}_{\text {str }}(\mathrm{t}) \text { domain } \\
\text { - Cyclical } \\
\text { characteristics } \\
\mathbf{I}_{\mathbf{M}}(\text { conjuncture }) \\
\text { of the hierarchy } \\
\text { of } \\
\text { external } \\
\text { environment of } \\
\mathrm{D}_{\text {str }}(\mathrm{t}) \text { domain }\end{array}$ \\
\hline
\end{tabular}

Tab. 2. Determinative factors of becoming / changewithin $D_{\text {str }}(t)$ domains

\section{Clustering and clusters as determinant factor of becoming / change}

A cluster is a grouping of a number of "something" (physical or abstract entities) potential competitive in its proximate external environment. The notion 
"cluster" is more and more used in science (physics, astrophysics, chemistry, biology, health sciences etc.), computing, economics, management etc. and have a systemic character. Yet, the cluster is not defined in a rigorous and systemic manner.

Despite its lack of profoundness, generality and conceptual clarity, (Martin \& Sunley, 2003), the notion of cluster has gained wide recognition as a model of industrial promotion and policies at both national and regional level (Porter, 1998; Press, 2006). Are known little and limited systemic approaches of cluster concept in economics (Sölvell, 2008; Jensen, 2009).

In our Universe, clusters are the systems of systems $\left\{S_{S}\right\}$ which generate becoming (progress / stagnation / regress) in space-time-resources domains $D_{\text {str }}(t)$ of natural and / or artificial environments, from macro-cosmos to micro-cosmos (Popa, 2003; Popa et al. 2009). Clusters are a mix of "self-determined internal environments $\left\{\mathrm{M}_{\text {aint }}\right\}$ \& target proximate external environment $\left\{\mathrm{M}_{\text {pext }}\right\}$ of $\mathrm{D}_{\mathrm{str}}(\mathrm{t})$, are the source for the increase of organized complexities, being implicitly innovative when created (a new structure in the outer environment). But, the lasting / sustainable progress in all domains is generated by inoclusters, by integrative-innovative clusters. (Popa, 2003, 2007).

The inoclusters (innovative clusters) are systems of real systems $\left\{S_{\mathrm{S}}\right\}$ generating progress in the natural and / or artificial environments, from macro cosmos to micro cosmos, in various time dimensions (transient, temporary, lasting, sustainable). The sustainable inoclusters generate progress in all natural and / or artificial environments, from macro cosmos to micro cosmos, on unlimited term, by the systems of real systems $\left\{\mathrm{S}_{\mathrm{S}}\right\}$ successive-parallel generations. Mankind tenaciously tends to turn into a sustainable macro-cluster, since the beginning of the $21^{\text {st }}$ century.

From a general functional-structural perspective, clusters are spatial-temporal agglomerations / concentrations of systems in $D_{\text {str }}(t)$ domains of the Universe (from macro-cosmos to micro-cosmos), having within their structure four categories of functional components (Table 1):

- three categories of components of the self-determined internal environment $\mathbf{M}_{\text {aint }}$ [1] Internal community (Comint) which gives the cluster its identity (crowd, group / team, network, colony, component society etc.) and provides / offers value / „range of products" for the consumers in the target proximate external environment $\mathrm{M}_{\text {pext }}$ [4],

[2] Internal and / or external facilitators (Facilit) which stimulate cooperation and competitiveness of the internal community components [1] and of the determinants [3],

[3] Determinants (Detint) of the self-determined internal environment $\mathbf{M}_{\text {aint }}$ specific features of the cluster which ensures the life and functioning of the internal community [1] and of internal and / or external facilitators [2],

- a category of components of target proximate external environment $\left\{\mathrm{M}_{\text {pext }}\right\}$

[4] External connectors (Conext) for components [1] \& [2] \& [3] which ensures the cluster's connexion with the target proximate external environment $\left\{\mathbf{M}_{\text {pext }}\right\}$ of $\mathbf{C}$ (initial suppliers and final consumers for cluster).

Irrespective of the category (natural and / or artificial), the clusters are implicit and transient innovators, by creating the $\mathrm{M}_{\mathrm{crS}}(\mathrm{t})$ critical masses of the components $\mathrm{E}$ and products that form the systems of real systems $\left\{S_{S}\right\}$, generators of becoming / 
change processes $(\ldots . \rightarrow$ progress $\rightarrow$ stagnation $\rightarrow$ regress $\rightarrow$ stagnation $\rightarrow$ progress $\rightarrow \ldots .$.$) .$

Clusters / inoclusters can be natural (created without human intervention) and / or artificial (created with human intervention). The infinity of the Universe and the complexity of life environment have determined and will continuously determine the clustering and the clusters characteristics, as follows:

(U) Infinite Universe in space-time-resources has generated and will generate, in a cyclic, successive-parallel and relatively slow manner, all the categories of natural clusters / inoclusters $\mathrm{S}_{\mathrm{SN}}$ :

- non-alive (physical-chemical, cosmological clusters etc.), in the entire Universe / Multiverse,

- alive (bio-clusters, bio-socio-clusters etc.), on the planets / satellites that provide favourable life conditions,

and

(L)planet Life environments, more and more complex, with more and more intelligent beings, have generated and will continue to generate, in a cyclic, successive-parallel way, at a certain moment, the categories of artificial clusters / inoclusters $S_{\mathrm{SA}}$, specific to human civilizations:

- spontaneous (self-adjusting clusters in external environment - for example, the pre-clusters in a certain economic sector, established by the companies that cooperate and strive for increasing competitiveness),

- planned, designed, accepted and established in various external environments (competitive durable clusters / competitive sustainable clusters - for example, the cluster established by a leading transnational company in global market).

Clustering is a continuous process of creation, functioning by current restructuring and dismissing of successive-parallel generations $g=1,2, \ldots, n, n+1$, ...., of clusters / clusters of clusters in $D_{\text {str }}(t)$ space-time-resources domains of the Universe which meet the existence requirements of $\left\{S_{S}\right\}$ systems of systems. An optimalclustering level $\mathrm{N}_{\text {Copt }}$ (Popa, 2007), defined by the maximal integrative competitiveness $K_{\text {ismax }}$ (sustainable), can be determined in any $D_{\text {str }}(t)$ domain.

The general model as illustrated in Figure 1 shows in details the universal cycle of systems becoming / change, considered as an sample (functional cycles $\mathrm{c}=1,2, \ldots, \mathrm{f}$ ) or as a type (system generations $\mathrm{g}=1,2, \ldots, \mathrm{s}$ ). The becoming / change of systems under review can be progress $(+)$, stagnation $(\approx)$ or regress $(-)$, in accordance with the evolution in time of the four major critical factors categories $\left\{\mathbf{f}_{\mathbf{c}}\right\}$ :

- dynamics characteristics of system outer environments $\mathbf{M}_{\mathbf{e x t}}$,

- dynamics characteristics of system inner environments $\mathbf{M}_{\mathbf{i n t}}$,

- specific change-generating critical masses $\mathbf{M}_{\mathbf{c r}}$ (clusters),

- integrative innovation in systems environments.

The progress in our Universe relies on competitive sustainable inoclusters (the progress-generating specific critical masses $\mathrm{M}_{\mathrm{cr}}$ and the integrative innovation in the system environments) within $D_{\text {str }}(t)$ space-time-resources domains.

In any space-time-resources domain $D_{\text {str }}(t)$ of the Universe characterized by stability within favourable / unfavourable limits for the existence of $\left\{S_{S}\right\}$ systems of systems, the clustering cyclically generates more complex E entities $(+\Delta \mathbf{W})$, more diverse $(+\Delta \mathbf{Z})$ and in big quantity $(+\Delta \mathbf{Q})$ that produce as exits more or less 
Popa, H. L.; Mocan, M. L.; Izvercianu, M. \& Pater, L. R.: Clustering and Clusters...

Internal environment $M_{\text {int }}$ of system $S_{R}[\mathrm{LCV}]$

$\checkmark$. Integrated policies and management $\mathbf{M}_{\mathrm{i}}(\mathbf{t})$ of the real systems $\mathrm{S}_{\mathrm{R}}$ with human operators

(person, team, organization, cluster, ...., federation of states) in $\mathrm{D}_{\mathrm{atr}}(\mathrm{t})$

CRISIS [LIP]〉.

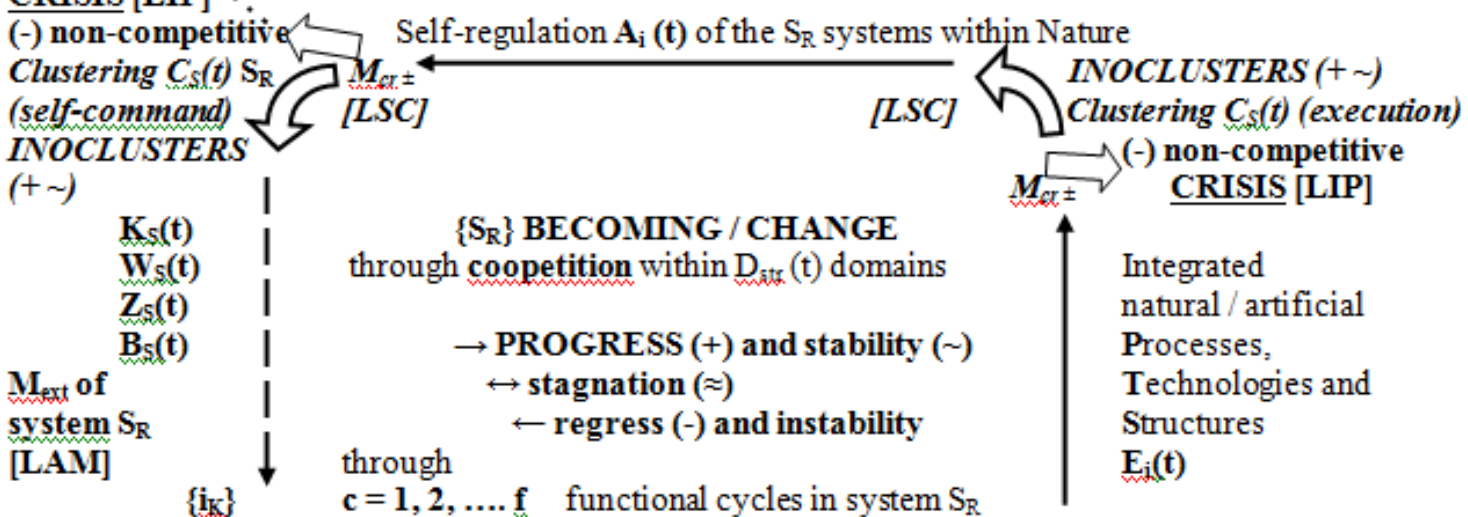

$\left\{\mathbf{i}_{\mathrm{K}}\right\}$

$\mathbf{c}=\mathbf{1}, \mathbf{2}, \ldots . \mathbf{f}$ functional cycles in system $\mathrm{S}_{R}$

CRISIS [LIF

(-) non-competitiv $[\mathrm{LSC}]$

Clustering $C_{S}(t)\left\{\mathrm{S}_{\mathrm{R}}\right\}$

INOCLUSTERS

(clusters of clusters)

Natural and artificial integrated Resources R(t)

(time, Substance, Energy, Information) in:

- Nature

- artificial environment within $\mathrm{D}_{\text {atr }}(\mathrm{t})$ setting up for Mankind.

External environment $\mathrm{M}_{\mathrm{ext}}$ of system $\mathrm{S}_{\mathrm{R}}[\mathrm{LAM}]$

Fig. 1. Principled model for the causal cycle of becoming / changing of real systems $\left\{S_{R}\right\}$ in the space-time-resources domains $D_{\text {str }}(t)$ of the Universe / Multiverse (?)

- Results of cyclic change through coopetition (COOPEration \& compeTITION) in sustainable time horizons (unlimited) / lasting (long term) / temporary (medium term) / ephemeral (short term)

$\boldsymbol{M}_{\boldsymbol{c r} \mathbf{E}^{-}}$critical mass, embryos of clustering $C_{S}(t)$

$\mathbf{C}_{S}(\mathbf{t})$ - Clustering of real systems $S_{R}$ in the hierarchy of external environments $\mathrm{M}_{\mathrm{ext}}$

$\left\{\mathbf{i}_{\mathrm{K}}\right\}$ - competitive assortments produced and transferred by $\mathrm{S}_{\mathrm{R}}$ to external environments $M_{\text {ext }}$ within $\mathrm{c}=1,2, \ldots \mathrm{f}$ cycles of the $\mathrm{g}=1,2, \ldots \mathrm{S}$ generations

$\mathbf{K}_{\mathbf{S}}(\mathbf{t})$ - Competitiveness of real systems $S_{R}$ in the hierarchy of external environments $\mathrm{M}_{\mathrm{ext}}$

$\mathbf{K}_{\text {tots }}(\mathbf{t})$-Sustainable total competitiveness mainly determining PROGRESS

$\mathbf{W}_{\mathbf{S}}(\mathbf{t})$ - Complexity of real systems $S_{R}$ in the hierarchy of external environments $\mathrm{M}_{\mathrm{ext}}$

$\mathbf{Z}_{\mathbf{S}}(\mathbf{t})$ - Diversity of real systems $S_{R}$ in the hierarchy of external environments $\mathrm{M}_{\mathrm{ext}}$

$\mathbf{B}_{\mathbf{S}}(\mathbf{t})$ - Welfare / Prosperity of real systems $S_{R}$ in the hierarchy of external environments $\mathrm{M}_{\mathrm{ext}}$

- Universal laws of real systems $\mathbf{S}_{\mathbf{R}}$ determine (Popa, 2003, 2008a) the causal cycle of becoming / changing of real systems $\left\{S_{R}\right\}$ in a $S_{R}$ space-time-resources existence domain $\mathbf{D}_{\text {str }}(\mathbf{t})$ : regular oscillation of resources and performances $( \pm)$; increase of performances $(\uparrow)$; decrease of performances $(\downarrow)$; lawful differentiation / distribution of systems, resources and performances $(\cap)$; limitation of resources and performances $(<)$ 
[LIP] - The law of existence (perfectible imperfection)

[major effects: $\pm \Delta \mathrm{K}_{\mathrm{S}}(\mathrm{t}) ; \mathrm{K}_{\mathrm{Sg}}(\mathrm{t})<\mathrm{K}_{\mathrm{SgMAX}}(\mathrm{t}) ;$ partial $\uparrow \mathrm{Z}_{\mathrm{S}}(\mathrm{t})$ ]

[LSC] - The law of change through clustering (competitiveness through inoclustering)

[major effects: $S_{R}$ distribution in accordance $\cap \mathrm{K}_{\mathrm{S}}(\mathrm{t}) ; \uparrow \mathrm{C}_{\mathrm{S}}(\mathrm{t})$; partial $\uparrow$ $\mathrm{W}_{\mathrm{S}}(\mathrm{t}) ;$ partial $\left.\uparrow \mathrm{K}_{\mathrm{S}}(\mathrm{t})\right]$

[LAM] - The law of equilibration / balance (environments self-adjusting law) [major effects: $\pm \Delta \mathrm{K}_{\mathrm{S}}(\mathrm{t}) ; \cap \mathrm{K}_{\mathrm{S}}(\mathrm{t}) ;$ partial $\uparrow \mathrm{W}_{\mathrm{S}}(\mathrm{t}) ;$ partial $\uparrow \mathrm{B}_{\mathrm{S}}(\mathrm{t})$ ]

[LCV] - The law of life (life cycle law)
[major effects: $\mathrm{K}_{\mathrm{Sg}}(\mathrm{t})<\mathrm{K}_{\mathrm{SgMAX}}$
$(\mathrm{t})$ şi $\mathrm{T}_{\mathrm{cvS}}$
$\left.(\mathrm{t})<\mathrm{T}_{\text {cvMAXS }} ; \downarrow \mathrm{K}_{\mathrm{S}}(\mathrm{t}) ; \pm \mathrm{B}_{\mathrm{S}}(\mathrm{t})\right]$

competitive $\{i\}$,products" $( \pm \Delta \mathbf{K})$ which become / may become resources for the next becoming / change cycles and determine more or less the $( \pm \Delta B)$ welfare in the $\mathbf{D}_{\text {str }}(\mathbf{t})$ domain. The internal clusters (of resources, execution, governing) and the clusters of clusters that give birth to the $\{\mathrm{i}\}$,,products" (Figure 1) are the main becoming / change generating factors. Integrative innovative clusters (inoclusters) $\mathrm{C}_{\text {ino }}$ are the only one to generate lasting / sustainable progress in the space-timeresources domain $\mathrm{D}_{\text {str }}(\mathrm{t})$ (Table 2).

Long time progress can be achieved within $D_{\text {str }}(t)$ space-time-resources domains only by the system lasting / sustainable integrative competitiveness $\mathbf{K}_{\mathbf{i d s}}$, as effect of the prevalence of positive critical factors / causes (+). The lasting $\mathbf{K}_{\mathbf{i d}} /$ sustainable $\mathbf{K}_{\text {is }}$ integrative competitiveness means the ability and the capacity of a $\left(\mathrm{S}_{\mathrm{S}}\right)$ system of systems to optimise from an integrative-hierarchy perspective its internal environment, to be a winner in the coopetition (confrontation and / or cooperation in successive-parallel cycles and generations) of its external environment, without causing damage, to simultaneously achieve welfare, for a very long (,lasting") / unlimited (,sustainable”) period of time.

At the Universe / Multivers scale, sustainable progress $(\ldots . \rightarrow$ cosmologic $\rightarrow$ biologic $\rightarrow$ anthropologic $\rightarrow$ humanist through civilization and culture $\rightarrow$ anthropologic $\rightarrow$ biologic $\rightarrow$ cosmologic $\rightarrow \ldots$..), on unlimited term can be achieved only if it is governed by intelligence, affections and a superior power. At the beginning of the $21^{\text {st }}$ century, Mankind is still far from meeting these requirements, but it has real chances to promote progress.

Stagnation is achieved through insufficient competitiveness $K$, as effect of the prevalence of neutral $(\approx)$ and contradictory $( \pm$ ) critical factors (causes).

Regress is achieved through non- competitiveness, as effect of the prevalence of negative (-) critical factors (causes) and crisis.

The general model as illustrated in Figure 1 and Table 2 shows four determinants of becoming / change of systems:

(1) periodical stability / instability of the hierarchical $D_{\text {str }}(t)$ space-time-resources domains features, in favourable / unfavourable limits of the each $D_{\text {str }}(t)$ space-timeresources domains life,

(2) hierarchical $D_{\text {str }}(t)$ space-time-resources domains internal and / or external clustering, like main generator of becoming / change, of self-organization,

(3) becoming / change cycle within each $\mathrm{D}_{\text {str }}(\mathrm{t})$ space-time-resources domains, like effect of universal / general / characteristic systems laws, 
Popa, H. L.; Mocan, M. L.; Izvercianu, M. \& Pater, L. R.: Clustering and Clusters...

(4) becoming / change category (progress / stagnation / regress) within $\mathrm{D}_{\text {str }}(\mathrm{t})$, like effect of competitiveness levels $\mathrm{K}(\mathrm{t})$ on the $\mathrm{D}_{\text {str }}(\mathrm{t})$ domains hierarchy.

The infinity of the Universe / Multiverse and the complexity of life environment have determined and will continuously determine the clustering and the clusters characteristics.

\section{The clustering in business and innovation environment}

In economy and innovation the clusters (synonyms: pôles de compétitivité France; Kompetenznetze - Germany) are dynamic agglomerations / bunches / geographical concentrations (street in a locality, ..., global market) of organizations, having within their maximal structure (innovative clusters / inoclusters) four categories of flexible / fluctuant integrated subsystems (Popa, 2002, 2005, 2007, 2008):

[1]Company networks (RF) with: [1.1] Leader companies ("product assemblers" or network coordinators) / groups of coordinating organizations in RF; [1.2] Innovation, production / services, sale, training companies; [1.3] ResearchDevelopment-Innovation companies (Universities, R\&D institutes / companies); [1.4] Financing institutions(Banks, non-reimbursement financing funds, national and EU financing programs etc.),

[2]Facilitators (Facilit): Institutions / organizations / networks for cooperation and competitiveness under stability or crisis conditions, with: [2.1] Centres of Competitiveness, Councils of Competitiveness; [2.2] Chambers of Commerce, Industry and Agriculture, other business organizations; [2.3] Development Agencies (regional, county, local); [2.4] Other facilitators: legal and monitoring institutions and bodies, employers associations, unions, professional organizations, media etc.

[3]Local PublicAdministration (LPA): [3.1] local / [3.2] regional / [3.3] euroregional / [3.4] national Government

[4]External connectors (Conext): Consumers on target markets / segments / niches with specific demand, in continuous behaviour changing and consumers from other proximal external environments (natural, demo-psycho-linguistic, sociocultural, political-juridical-administrative, military etc), Initial Suppliers from external environments.

In a strict sense, clustering ("cluster development" or "cluster initiative") is defined as business and innovation cluster establishment and development in economy.

Clusters are created and develop in a natural or planned manner in the geographic / administrative regions, in villages, towns, cities / municipalities, areas, counties. Based on the cluster definition, any inhabited locality or region, by means of the local public administration, is co-determinant for the establishment of one or several clusters belonging to some distinctive economic branches / sectors.

The factors that determine clustering and cluster development and competitiveness in the business and innovation, technological and managerial environments at the beginning of the $21^{\text {st }}$ century are very numerous. The most important are the following: 
- culture and skills of partners from the cluster (determine cluster establishment and influence $\mathrm{C}_{\mathrm{KC}}$ competing capacity of clusters)

- cooperation and competitiveness culture, common beliefs and competence of partners

- trust and lasting respect among partners as basis for cooperation development

- integrative innovation and extended innovative spirit, as basis for clusters progress

- learning / imitation and coopetition (cooperation and competition), as basis for adaptability

- proactive / developed entrepreneurship in all cluster components, within the cluster as a whole, as basis for cluster dynamism

- knowing / acquiring integrative management of competitiveness (Popa, 2008b)

- external conjunctures of cluster and cluster components(determine cluster promotion, establishment, development, certification and longevity, cluster lifecycle duration $\mathrm{T}_{\mathrm{cvC}} \rightarrow$ max; or, determine cluster termination)

- conjunctures at micro / mezzo level (communities, organizations outside the clusters / counties)

- conjunctures at macro level (regions, states, state federations, expansions / national, federal economic and political crises etc.)

- conjunctures at global level (climate, biodiversity, pollution, wars, terrorism, lack of resources, expansions / world economic and political crises, demographic crisis etc.)

- resources, cluster internal and external connexions (determine cluster creation, development, certification and longevity, cluster life-cycle duration $\mathrm{T}_{\mathrm{cvC}} \rightarrow \max$ )

- nominal capital concentrated in the geographic area, determining communication, trust and continuous expansion of cooperation among people and organizations of various categories, with a view to simultaneously developing individual and community value

- creation of competitive multidimensional networks, capable of flexible and agile cooperation

- qualified / poly-qualified labour force by means of continuous training

- continuous communication with the outside, in order to identify / foresee opportunities and dangers in real time

- specific material resources (infrastructure, high tech machines and equipment, natural resources etc.),

- financial resources for cluster various life cycles stages,

- necessary informational resources (integrative management, know-how etc.).

Clustering in business and innovation environment is carried out under several stages and phases (Potworowski, 2003; Popa, 2008; Sölvell, 2008) in the framework of cluster life cycles. The following are the most important ones of these stages:

(1) Mobilization - development of interest, knowledge and participation of various organizations as potential members of the future cluster

$\sim$ orientation of the organization creation / designation (leader company, group of companies, association etc.) for the cluster establishment, dedicated to fulfil its goals

$\sim$ creation of a project team and a council for monitoring the cluster establishment 
Popa, H. L.; Mocan, M. L.; Izvercianu, M. \& Pater, L. R.: Clustering and Clusters...

$\sim$ identification and evaluation of ,pre-cluster potential embryos (GP)” (dynamic, offensive companies C / Networks of Companies NC) and of (PC) pre-clusters with local cluster establishment potential

$\sim$ recruitment of highly cluster-oriented and committed leaders

$\sim$ identification of economic / innovative opportunities and incentives, attractive for those interested in increasing competitiveness by means of clustering

$\sim$ stimulation of private / public organizations interest in participating to cluster / pre-cluster oriented actions

stimulation of cluster potential interested bodies and "champions"

(2) Diagnosis and prognosis - evaluation of resources, marketing opportunities and infrastructure necessary to an effective cluster

$\sim$ attraction of an independent, objective analyst

$\sim$ analysis and group diagnosis / prognosis by advanced methods (complex SWOT analysis, benchmarking etc.) for long and medium term definition:

(3) Cluster and clustering cooperation strategy - working group analysis with competent representatives ([1] Network of organizations \& [2] Facilitators \& [3] Local Public Administration) of cluster challenges, potentiality, priorities and elaboration of cluster policy / strategy

$\sim$ organization of work meetings for the confrontation of opinions and the commitment of the organizations in the future cluster

$\sim$ organization of a complete, open working group (critical mass), oriented towards the market and the environment, to define the stages in the cluster establishment and development

$\sim$ selection of a competent working group able to recruit participants in the cluster and monitor the stages in the cluster establishment

$\sim$ determination of viability for each stage and training of interested bodies

$\sim$ formulating the clustering strategy and cooperation for cluster establishment

$\sim$ applying the cooperation strategy to cluster establishment

(4) Cluster establishment - expanding the group of interested organizations, creating / designating an organization to create and establish the cluster de facto

$\sim$ creation of a group to control and promote cluster establishment

$\sim$ facilitating cluster sales and procurement by expanding company networks

$\sim$ expansion of cluster financing sources

$\sim$ development of cluster oriented leadership

$\sim$ cluster juridical and physical establishment $\mathbf{C C}$ (alliances-group, leader company that ,assemblies” complex products, coordinating-company, organization associations etc.)

$\sim$ involvement of clusters in regional development and social responsibility

(5) Cluster operation by regular restructuring and increase of competitivenessdevelopment of competitive cluster / generations of sustainable competitive clusters on extended markets: local, ...., global

$\sim$ cluster development at regional level $\mathrm{CD}$, based on competitiveness strategies and tactics, with regular sub-improvements

$\sim$ cluster initial certification - at regional / euro-regional level

$\sim$ cluster development at national level CE, based on competitiveness strategies and tactics, with regular sub-improvements 


\begin{tabular}{|c|c|c|c|c|c|c|c|c|c|c|}
\hline & Target & micro & 1 & Mezz & 1 & & MAC & & & \\
\hline Leve & market & street & district & locality & area & county & region & country & federation & global \\
\hline & $\begin{array}{l}\text { Cluster } \\
\text { leader in } \\
\text { global } \\
\text { market } \\
\end{array}$ & & & & & & & & & $\bullet$ \\
\hline & $\begin{array}{l}2 \text { Cluster } \\
\text { in Top } 3 \\
\text { worldwide }\end{array}$ & & & & & & & & $\bullet$ & $\bullet$ \\
\hline CE & $\begin{array}{l}3 \text { Cluster } \\
\text { in Top 10 } \\
\text { worldwide }\end{array}$ & & & & & & & & - & $\bullet$ \\
\hline & $\begin{array}{l}\mathbf{4} \\
\text { Clusterimportant } \\
\text { interna- } \\
\text { tional } \\
\end{array}$ & & & & & & $\bullet$ & $\bullet$ & $\bullet$ & \\
\hline & $\begin{array}{l}\mathbf{5} \\
\text { Clusterimportant } \\
\text { federal }\end{array}$ & & & & & & $\bullet$ & - & - & \\
\hline & $\begin{array}{l}\mathbf{6} \\
\text { Clusterimportant } \\
\text { national }\end{array}$ & & & & & 证 & $\bullet$ & • & & \\
\hline CD & $\begin{array}{l}7 \\
\text { Clusterimportant } \\
\text { regional }\end{array}$ & & & $\bullet$ & $\bullet$ & • & • & & & \\
\hline & $\begin{array}{l}\mathbf{8} \\
\text { Clusterimportant } \\
\text { at level } \\
\text { area } \\
\end{array}$ & & - & - & - & & & & & \\
\hline CC & $\begin{array}{l}9 \\
\text { Clusterimportant } \\
\text { local }\end{array}$ & - & - & - & & & & & & \\
\hline & $\begin{array}{l}10 \text { Establish } \\
\text { Cluster }\end{array}$ & $\bullet$ & $\bullet$ & - & - & - & $\bullet$ & & & \\
\hline PC & $\begin{array}{l}\text { 11 Existing } \\
\text { Pre-Cluster }\end{array}$ & O & O & $\mathbf{O}$ & O & O & O & & & \\
\hline GP & $\begin{array}{l}12 \text { Potential } \\
\text { embryonic } \\
\text { Pre-Cluster }\end{array}$ & $\begin{array}{l}\text { Firm / } \\
\text { Network }\end{array}$ & $\begin{array}{l}\text { Firm / } \\
\text { Network }\end{array}$ & $\begin{array}{l}\text { Firm / } \\
\text { Network }\end{array}$ & $\begin{array}{l}\text { Firm / } \\
\text { Network }\end{array}$ & & & & & \\
\hline
\end{tabular}

Tab. 3. Priorities in analysis, promotion, establishment, assessment and clusters C certification

$\mathbf{K}_{\mathbf{C}}-$ cluster $\mathrm{C}$ competitiveness (level of target market and market share)

$\mathbf{C E}$ - International Extended Cluster (cluster competitiveness level $\mathrm{K}_{\mathrm{C}}=1, \ldots .5$ )

CD - National and regional Developed Cluster (cluster competitiveness level $K_{C}=6,7$ )

CC - Regional, local, establish Cluster (cluster competitiveness level $\mathrm{K}_{\mathrm{C}}=8,9,10$ )

PC - Natural Pre-cluster (cluster competitiveness level $K_{C}=11$ )

GP - Potential embryonic Pre-cluster

- - Preferable analysis, promotion, establishment, assessment and clusters $C$ certification

$\mathbf{O}$ - Preferable assessment and promotion of pre-clusters PC

$\sim$ cluster second certification - at national level (ex. France in $2004 \& 2008$ ) 
$\sim$ cluster development at European / global level CE, based on competitiveness strategies and tactics, with regular sub-optimization

$\sim$ cluster third certification - at European / global level (ex. in UE, European Cluster Observatory, active after 2007)

In all the countries that lack competitiveness, the managerial and political culture (scientific management, clusters and clustering, competitiveness policies and management etc.) is rather precarious at all levels and the domestic capital clusters are very rare or they do not exist at all. In these countries, there are pre-clusters PC naturally established, within 3 - 10 years since the establishment of the leader company (of ,product assembler” or „,network assembler” type). In case these countries attract important direct investments, the transfer of resources (management, technologies, cooperation and quality culture, financing etc.) is effected relatively easy and through the following:

- rapid establishment of regional clusters $\mathbf{C E}$ linked to the global market by means of „foreign mother-companies” (solution used by all multinational exporting companies),

- link / inclusion of efficient domestic companies and foreign companies operating on the national territory to the clusters of clusters of trans-national companies,

- short-time establishment of a national / global cluster by a joint venture or foreign leader company acting as a „complex product assembler" (ex. The automotive cluster in Romania, having as leader company Dacia Group Renault Pitesti, with $1881^{\text {st }}$ rank suppliers of which 54 from Romania and thousands of suppliers on the national and global market, was ser up in 4 years, 2000-2004)

In the countries and regions where the clustering process is rather slow, the analysis, promotion, establishment, evaluation and certification of clusters / clustering shall be done within a more complex / comprehensive vision (Table 3), starting with "pre-cluster potential germs (GP)", to be identified in the top of competitive companies, which can "crystallize" pre-clusters and clusters.

\section{Conclusion}

The modern science progresses when a more general theory is formulated, which explains as many phenomena as possible with as few statements as possible. This idea, that more general theories are preferred over more specialized theories, lies at the heart of systems science.

The clustering systemic approach explains a great number of phenomena related to the becoming / change in the most diversified domains while using a small number of concepts and models.

The present article presents in details the new research and action sub-domain defined as "cluster-based sustainable integrative competitiveness (on unlimited term)", by the following contributions:

» integrative definition of the main concepts of systemics,

» functional-structural definition and characterization of clusters, clustering and inoclusters, which allows the systemic approach and the unitary application of these concepts, in most various domains of reality [science (physics, astrophysics, chemistry, biology, health sciences etc.), computing, economics, engineering, management, policies, politics etc.], 
» elaboration of a model for the universal cycle of the system becoming / change, which emphasizes the essence of progress in any domain of reality: cluster-based sustainable integrative competitiveness,

» systemic analysis of clustering within business and innovation environments, of the progress ways in this domain.

Future research will go deeper in the identification and optimization of clustering and clusters / clusters of clusters in other complex domains of reality (science, engineering, management, economics, policies, politics, culture etc.).

\section{References}

Adams, F. \& Gregory, L. (2000). The Five Ages of the Universe: Inside the Physics of Eternity, Simon \& Schuster Australia, ISBN 0-684-86576-9, Sydney

Banathy, B. (2000). Guided Evolution of Society: A Systems View, Springer, ISBN 9780306463822, New York

Castellani, B. \&Hafferty, F.W. (2009). Sociology and Complexity Science. A New Field of Inquiry, Springer, ISBN 978-3-540-88461-3, New York

Chaisson, E. (2001). Cosmic Evolution: The Rise of Complexity in Nature, Harvard University Press, ISBN 0-674-00342-X, Cambridge

Costanza, R. et al. (2009). Beyond GDP: The Need for New Measures of Progress, The Pardee Papers, no. 4, January 2009, Boston, ISBN 978-0-9825683-0-9

Dick, S. (2008). The postbiological universe, Acta Astronautica, Volume 62, Issues 8-9, April-May 2008, p.499-504, ISSN 0094-5765

Dyson, F. (1989). Time without End: Physics and Biology in an Open Universe, Review of Modern Physics 51, no. 3, p.447-460, ISSN 1539-0756

François, C. (1999). Systemics and Cybernetics in a Historical Perspective, Systems Research and Behavioral Science, Vol 16, p.203-219, ISSN 1092-7026

Harrison, E. (2003). Masks of the Universe: Changing Ideas on the Nature of the Cosmos, Cambridge University Press, ISBN 0-521-77351-2, Cambridge

Jensen, S.A. et al. (2009). Aspects of a cluster research strategy: systemics applied to the study of clusters, Kybernetes: The International Journal of Systems \& Cybernetics, Vol. 38, No. 1-2, p. 201-216, ISSN: 0368-492X

Katseneliboigen, A. (1997). Evolutionary change: toward a systemic theory of development and maldevelopment, CRC Press, ISBN 9789056995294, Boca Raton

Kauffman, S. (1997). At Home in the Universe. The Search of Laws of Self-Organization and Complexity, Oxford University Press Inc., ISBN 978-0195111309, Oxford

Martin, R. \& Sunley, P. (2003). Deconstructing Clusters: Chaotic Concept or Policy Panacea?, Journal of Economic Geography, Vol. 3, No. 1, January, p. 5-35, ISSN 1468

Moore, G.M. (1994). On Progress: Its Reality, Desirability and Destiny, Hoover Institution, Stanford University, Stanford

Popa, H.L. et al. (2002). Management strategic, Editura Dacia, ISBN 973-35-1524-8 167, Cluj-Napoca

Popa, H.L. (2003). Teoria şi ingineria sistemelor. Concepte, metode, modele, competitivitate, Editura Politehnica, ISBN 973-8247-74-8, Timişoara

Popa, H.L. (2005). Managementul competitivităţii pentru întreprinderi industriale româneşti, Revista de Politica Ştiinţei şi Scientometrie, - Număr Special 2005 - p. 101-156, ISSN-1582-1218

Popa, H.L. (2007). The integrative competitiveness. A systemic approach, Scientific Bulletin of the "POLITEHNICA" University of Timişoara, Romania, Transactions on 
Popa, H. L.; Mocan, M. L.; Izvercianu, M. \& Pater, L. R.: Clustering and Clusters...

Management. Engineering Economy. Transportation Engineering, Tom 52 (66), Fasc.1, 2007, p. 5-18, ISSN 1224-6050

Popa, H.L.; Pater, L.R. \& Cristea, S.L. (2008): Managementul competitivităţii serviciilor, Editura Politehnica, Timisoara, ISBN 978-973-625-648-6

Popa, H.L. (2008a). Sustainable competitive inoclusters. A systemic approach, Scientific Bulletin of the "POLITEHNICA" University of Timişoara, Romania, Transactions on Management. Engineering Economy. Transportation Engineering, Tom 53 (67), Fasc. 1, 2008, p. 5-16, ISSN 1224-6050

Popa, H.L. (2008b). The competitiveness management of clusters, Scientific Bulletin of the "POLITEHNICA" University of Timisoara, Romania, Transactions on Management. Engineering Economy. Transportation Engineering, Tom 53 (67), Fasc.2, p. 5-32, ISSN 1224-6050

Popa, H. L.; Mocan, M. L.; Izvercianu, M. \& Pater, L. R. (2008). Competitiveness Strategies and Tactics for the International Scientific - Academic Associations and Clusters, Chapter 52 in DAAAM International Scientific Book 2008, pp. 613-620, B. Katalinic (Ed.), Published by DAAAM International, ISBN 3-901509-69-0, ISSN 1726-9687, Vienna, Austria

Popa, H. L.; Izvercianu, M.; Mocan, M. L. \& Pater, L. R. (2009). A Systemic Definition of Clusters, Annals of DAAAM for 2009 \& Proceedings of the 20th International DAAAM Symposium, p. 0455-0457, ISBN 978-3-901509-70-4, ISSN 1726-9679, p. 228, Editor B[ranko] Katalinic, Published by DAAAM International, Vienna, Austria Porter, M.E. (1998). The competitive Advantage of Nations, Free Press, ISBN 0-684-841479, New York

Press, K. (2006). A Lifecycle for Clusters? The Dynamic of Agglomeration, Change, and Adaptation, Physica-Verlag, ISBN 978-3-7908-1710-2, Heidelberg

Potworowski, A. (2003). Creating and Growing Technology Clusters: Observations and best practices from NRC managers engaged in the creation and development of technology based clusters, Technology Management Associates, Ottawa, Canada

Sölvell, Ö. (2008). Clusters. Balancing Evolutionary and Constructive Forces, Ivory Tower Publishers, ISBN 978-91-974783-3-5, Stockholm

Stiglitz, J. (2009). Progress, what progress?, OECD Observer, No 272, March 2009, p.11-12

Stonier, T. (1990). Information and the Internal Structure of the Universe, Springer, ISBN 978-3540195993, Berlin

Stonier, T. (1992). BeyondInformation: The Natural History of Intelligence, Springer, ISBN 978-3540196549, New York

Stonier, T. (1997). Information and Meaning: An Evolutionary Perspective, SpringerVerlag Telos, ISBN 978-3540761396, New York

Teilhard de Chardin P. (1948/1956). Le Phénomène Humain, Rome, 1948 / Editions du Seuil, Paris, 1956

Umpleby, S.A. (2001). Two Kinds of General Theories in Systems Science, Proceedings of the American Society for Cybernetics, Vancouver, p. 69-75, Available from:http://www.asc-cybernetics.org/2001/Umpleby.htm, Accessed: 2010.04.05

Umpleby, S.A. (2007). Physical Relationships among Matter, Energy and Information, Systems Research and Behavioral Science, Vol. 24, No. 3, p. 369-372, ISSN 10927026

Watson, D.E. et al. (1999). The Theory of Enformed Systems: A Paradigm of Organization and Holistic Systems, The Noetic Journal 2 (2), p.159-172, ISSN 1094-0359

Wright, R. (2005). A Short History of Progress, Da Capo Press, ISBN 978-0786715473, New York 